OPEN ACCESS

Edited by: Maria Efthymiou, University College London, United Kingdom

Reviewed by: Inês Cardoso Leal,

Santa Maria Hospital, Portugal Victor Llorens,

Hospital Clínic de Barcelona, Spain

${ }^{*}$ Correspondence: Yanlin Zheng zhengyanlin@cdutcm.edu.cn

Specialty section: This article was submitted to Inflammation Pharmacology, a section of the journal Frontiers in Pharmacology

Received: 28 February 2021 Accepted: 07 April 2021 Published: 26 April 2021

Citation: Li B, Li H, Zhang L and Zheng Y (2021) Efficacy and Safety of Adalimumab in Noninfectious Uveitis: A Systematic Review and Meta-Analysis of Randomized Controlled Trials. Front. Pharmacol. 12:673984. doi: 10.3389/fphar.2021.673984

\section{Efficacy and Safety of Adalimumab in Noninfectious Uveitis: A Systematic Review and Meta-Analysis of Randomized Controlled Trials}

\author{
Biao Li, Haoran Li, Li Zhang and Yanlin Zheng* \\ Department of Ophthalmology, Affiliated Hospital of Chengdu University of Traditional Chinese Medicine, Chengdu, China
}

Background: Patients with noninfectious uveitis (NIU) are at risk of systemic side effects of long-term glucocorticoid therapy and uncontrolled inflammatory complications. In urgent need to identify more aggressive therapies, adalimumab (ADA) may be the right choice.

Objectives: To summarize the current evidence from randomized controlled trials (RCTs) regarding the efficacy and safety of ADA in the treatment of NIU.

Methods: We searched Pubmed, Embase, Web of Science, Cochrane Library databases, and Clinical Trials Registry for qualifying articles from their inception to November 19, 2020, with no language restriction. Randomized controlled trials comparing ADA with conventional routine treatment in noninfectious uveitis patients of any age, gender, or ethnicity were included. The primary outcome was the time to treatment failure (TF). The secondary outcomes were the change in best-corrected visual acuity (BCVA), change in the anterior chamber $(\mathrm{AC})$ cell grade, change in vitreous haze $(\mathrm{VH})$ grade, and adverse events (AEs).

Main results: The six studies comprised 605 participants in all, and the sample size of each study ranged from 16 to 225 . The overall pooled results of the primary outcome ( $H R=$ $0.51 ; 95 \% \mathrm{Cl}, 0.41$ to -0.63$)$ showed that ADA nearly halved the risk of treatment failure compared to placebo for NIU patients. The pooled mean difference of change in BCVA was $-0.05(95 \% \mathrm{Cl},-0.07$ to -0.02$)$. The pooled mean difference of change in AC cell grade and $\mathrm{VH}$ grade was $-0.29(95 \% \mathrm{Cl},-0.62$ to -0.05$)$ and $-0.21(95 \% \mathrm{Cl},-0.32$ to $-0.11)$, respectively. The incidence of AEs in the ADA group was numerically higher than that of $A E s$ in the placebo group (2,237 events and 9.40 events per patient-year, equivalent to 1,257 events and 7.79 events per patient-year).

Conclusion: This meta-analysis of six RCTs further confirmed that ADA considerably lowered the risk of treatment failure or visual loss, and moderately reduced $A C$ cell grades and $\mathrm{VH}$ grades with slightly more AEs, as compared to placebo. ADA is both effective and safe in treating NIU.

Systematic Review Registration: [https://clinicaltrials.gov], identifier [CRD42020217909].

Keywords: adalimumab, noninfectious uveitis, anti-TNF- $\alpha$, treatment, meta-analysis 


\section{INTRODUCTION}

Noninfectious uveitis (NIU) encompasses a heterogeneous collection of ocular disorders related to different etiologies, characterized by intraocular inflammation in the absence of infection (Airody et al., 2016; Dick et al., 2016). It is generally believed that noninfectious uveitis is an immune-mediated ocular inflammation frequently accompanied by systemic autoimmune diseases such as juvenile idiopathic arthritis, Behcet syndrome, or ankylosing spondylitis (Cordero-Coma and Sobrin, 2015; Schwartzman and Schwartzman, 2015). The mean prevalence of uveitis in Europe is 144.85 in 100,000 people, while NIU approximately accounts for $70 \%$ of uveitis (Llorenç et al., 2015). Simultaneously, the gross prevalence of NIU in American adults is roughly calculated to be $121 / 100,000$ (Dick et al., 2016). It is estimated that the risk of blindness or low vision in patients with NIU is ten times higher than that in people without NIU (Durrani et al., 2004). NIU accounted for approximately $20 \%$ of legal blindness in developed countries, causing a massive burden to society (Nussenblatt, 2005; Wakefield and Chang, 2005; Jabs et al., 2013).

The treatment principle of NIU is to control intraocular inflammation, prevent relapses of inflammation, and reduce drug-related side effects. Currently, corticosteroids and immunosuppressants remain the mainstay of treatment drugs, which sometimes fail to control inflammation and frequently cause well-known ocular and systemic adverse effects (Sen et al., 2014; Miloslavsky et al., 2017; Niederer et al., 2017; Suhler et al., 2017). Therefore, it is urgent to identify more effective and safer therapies that target specific immune response mediators to achieve and maintain inflammation remission. Moreover, adalimumab (ADA) may be the one (Suhler et al., 2013; LevyClarke et al., 2014).

Adalimumab (Humira ${ }^{\circledR}$; AbbVie Inc.) is a full-length human monoclonal antibody that uniquely targets TNF- $\alpha$ and counteracts its biological activity (Burmester et al., 2013; Airody et al., 2016; Balevic and Rabinovich 2016). Currently, ADA is the only biologic that has been proven effective to NIU by randomized-control, double-blind phase III studies (Jaffe et al., 2016; Nguyen et al., 2016). Consequently, the United States, European countries, Japan, and China have successively approved ADA to treat NIU. Although it received approval in these countries, ADA has not yet been widely used worldwide.

The most recent systematic review on the ADA for NIU dates back to 2018 (Ming et al., 2018), while several relevant articles have been published after that. Moreover, all the existing systematic reviews on this topic are mainly based on observational studies and rarely include randomized controlled trials (RCTs) which lead to their low quality of evidence. So we herein conducted a systematic review with meta-analysis to synthesize the currently accessible evidence from RCTs to assess ADA's efficacy and safety in NIU.

\section{ARTICLE TYPES}

A Systematic Review and Meta-Analysis of RCTs.

\section{MANUSCRIPT FORMATTING}

\section{Methods}

This meta-analysis was conducted following the Preferred Reporting Items for Systematic Review and Meta-analysis statements (Shamseer et al., 2015), with the protocol registered in the Prospero database (CRD42020217909).

\section{Study Design and Interventions}

The main inclusion criteria are as follows: 1) randomized controlled trials comparing $\mathrm{ADA}$ with conventional routine treatment (such as local and systemic corticosteroids, immunosuppressants) in patients of any age, gender, or ethnicity with a diagnosis of NIU; 2) the mean follow-up duration was more than three months; 3) sample size greater than 10 ;4) AC cell grade and $\mathrm{VH}$ grade were evaluated by Standardization of Uveitis Nomenclature (SUN) criteria (Jabs, Nussenblatt, and Rosenbaum, 2005). We excluded studies that met any of the following conditions: 1) duplicate reports on the same study; 2) inadequate data or information; 3) control group was not placebo.

\section{Data Sources and Search Strategy}

Pubmed, Embase, Web of Science, Cochrane Library, and Clinical Trials Registry were searched for relevant literature from their inception to November 19, 2020, regardless of language. If necessary, the researchers were contacted for more data. The search was limited to abstract/keyword/title fields. The search terms included uveitis, iridocyclitis, retinitis, retinal vasculitis, panuveitis, uveit*, adalimumab, ADA, Humira, TNF, TNF-a, anti-tumor necrosis factor-alpha, randomized controlled trial, and clinical trial. The Boolean operators appropriately connected these keywords. Study design types were restricted to randomized controlled trials (RCTs).

\section{Study Selection and Exclusion Processes}

According to the inclusion criteria, two reviewers (Biao $\mathrm{Li}$ and Haoran Li) independently assessed the relevant studies for eligibility. Any disagreements were resolved through discussion among ourselves.

\section{Outcomes Assessment}

The primary outcome was the time to treatment failure (TTF), a rigorous composite outcome composed of four components (new ocular inflammatory lesions, BCVA, AC cell grade, and VH grade). "Treatment failure" was defined by the presence of one or more of the following factors: 1 . new active, inflammatory lesions relative to baseline; 2. a two-step increase in anterior chamber cell or vitreous haze grade; 3 . a worsening of best-corrected visual acuity by 15 or more letters on the Early Treatment Diabetic Retinopathy Study chart, relative to the best state previously achieved, in at least one eye; 4 . sustained non-improvement with entry grade of $\geq 3$; 5 . use of concomitant medications not allowed; and 6. intermittent or continuous suspension of study treatment (adalimumab or placebo) for a cumulative period of longer than four weeks. The secondary efficacy outcomes included change in BCVA (logMAR), change in AC cell grade, and VH grade (according to SUN). The 
safety outcome was the number and the rate of adverse events (per patient-years).

\section{Data Extraction}

Two authors (Biao Li and Haoran Li) extracted the data from the included publications into standard forms independently and cross-checked them to ensure accuracy. Differences were settled by discussion and transferred to a third author if needed. The information captured included: first author's last name, published date, number of patients in each group, demographic data, follow-up time, and definitions of endpoints. If the same registered trial data appeared in multiple articles, the article with the latest or most comprehensive data was included.

\section{Data Analysis}

Two reviewers (Biao Li and Li Zhang) independently evaluated the quality of the included studies using the recommended Cochrane Collaboration tool for assessing the risk of bias, which consists of seven types of risks of bias: random sequence generation; incomplete outcome data; allocation concealment; selective reporting; blinding of participants and personnel; blinding of outcome assessment; for-profit bias. Disagreements were settled by discussion and transferred to a third author if needed. We conduct our statistical analysis using review manager version 5.3 software according to the intention to treat analysis method. The evaluation of outcomes was done per eye, except TF and AEs, mainly pooled per patient. For continuous endpoints such as BCVA, AC cell grade, and $\mathrm{VH}$ grade, we preferentially retrieved mean differences with 95\% CI. When meta-analysis was not proper for certain types of data we narratively summarize the relevant results.

The heterogeneity of the pooled results was assessed by Cochrane's Q test and Higgins' ${ }^{2}$. If apparent heterogeneity existed $\left(p<0.1\right.$ or $\left.\mathrm{I}^{2}>50 \%\right)$, the pooled results were estimated using the random-effects model. Alternatively, the fixed-effects model was adopted. Besides, we deleted each study to assess each study's impact on the overall risk estimate to examine the results' robustness. Subgroup analysis was initially planned according to the type of uveitis, study location, follow-up time duration, and participants' age. Unfortunately, we do not have enough sample size to perform these analyses.

We originally planned to examine the publication bias of included studies by funnel plots and Egger's test. Unfortunately, we lack enough studies to conduct these analyses.

\section{Confidence in Cumulative Evidence}

The GRADE system was used to access the evidence's quality of every efficacy outcomes. GRADE system scored the evidence of each outcome in five aspects: limitations of the study design and execution, inconsistency, indirectness, imprecision of results, and publication bias. Accordingly, we classify ADA treatment's recommendation level as very low, low, medium, or high.

\section{Results}

\section{Study Selection}

Our literature search yielded 918 articles (Pubmed: 335; Embase: 292; Web of Science: 161; Cochrane Library: 113;
ClinicalTtrials.gov: 17). After removing duplicates, 616 articles remain. Of these, 568 were excluded after screening for the titles and abstracts. After the full-text examination of the remaining 48 articles, five articles ( 6 trials, there was one article containing the data of two RCTs) met inclusion criteria for our meta-analysis (Figure 1).

\section{Study Characteristic}

All six studies used intention-to-treat analysis to evaluate efficacy and safety outcomes. Six hundred thirty-six patients were enrolled in six studies, including 318 in the ADA group and 287 in the control group. The sample size ranged from 16 to 225 . Overall, $61.23 \%(368 / 601)$ of patients were female, with the sex distribution favored females in each of the six studies. The mean age varied from 8.90 to 50.90 years old, and the mean uveitis duration was between 43.75 and 94.56 months. Table 1 summarises the characteristics of the six selected RCTs.

\section{Quality Assessment}

We judged for-profit bias in all six studies as high risk since five of the included studies were sponsored by pharmaceutical companies (AbbVie), while the remaining one studies had participants who received remuneration such as speaker's fees from AbbVie.

Since only outcome assessors were blinded in Mackensen's study, the risk of performance bias was considered high, and the detection bias was assessed as low risk. In the other five studies, the risk regarding blinding were all considered low risk since the methods of blinding patients, doctors, and outcome assessors were described in detail. The remaining four types of risk of bias were all considered low risk in six studies because the corresponding evidence can be found in the article. As prospective trial registrations were accomplished in all studies and their prespecified outcomes were reported, selective reporting was considered low risk. Figure 2 demonstrates the risk of bias in each study.

\section{Synthesis of Results}

The pooled results included the time to treatment failure, change in AC cell grade, change in $\mathrm{VH}$ grade, and change in BCVA ( $\log M A R)$. Table 2 demonstrates the relevant results of the including studies.

\section{Time to Treatment Failure}

The hazard ratio (HR) to treatment failure was reported in five studies. All studies reported the HRs ranging from 0.25 to 0.57 , except for the VISUAL I Japan (HR = 1.2, 95\% CI, 0.41-3.51). The pooled results of all the five studies $(\mathrm{HR}=0.51 ; 95 \% \mathrm{CI}$, 0.41-0.63) showed that ADA nearly halved the risk of treatment failure compared to placebo. Heterogeneity was not significant by the Q statistic (6.49 on $4 \mathrm{df}, p=0.17$ ) and by $I^{2}(38 \%)$. (Figure 3)

\section{Change in BCVA (logMAR)}

A total of five studies involving 856 patients presented the change in BCVA (logMAR) after the intervention. The mean difference of the change in BCVA ranged between -0.08 and $0.04(p<0.05)$. The pooled estimate mean difference favored 


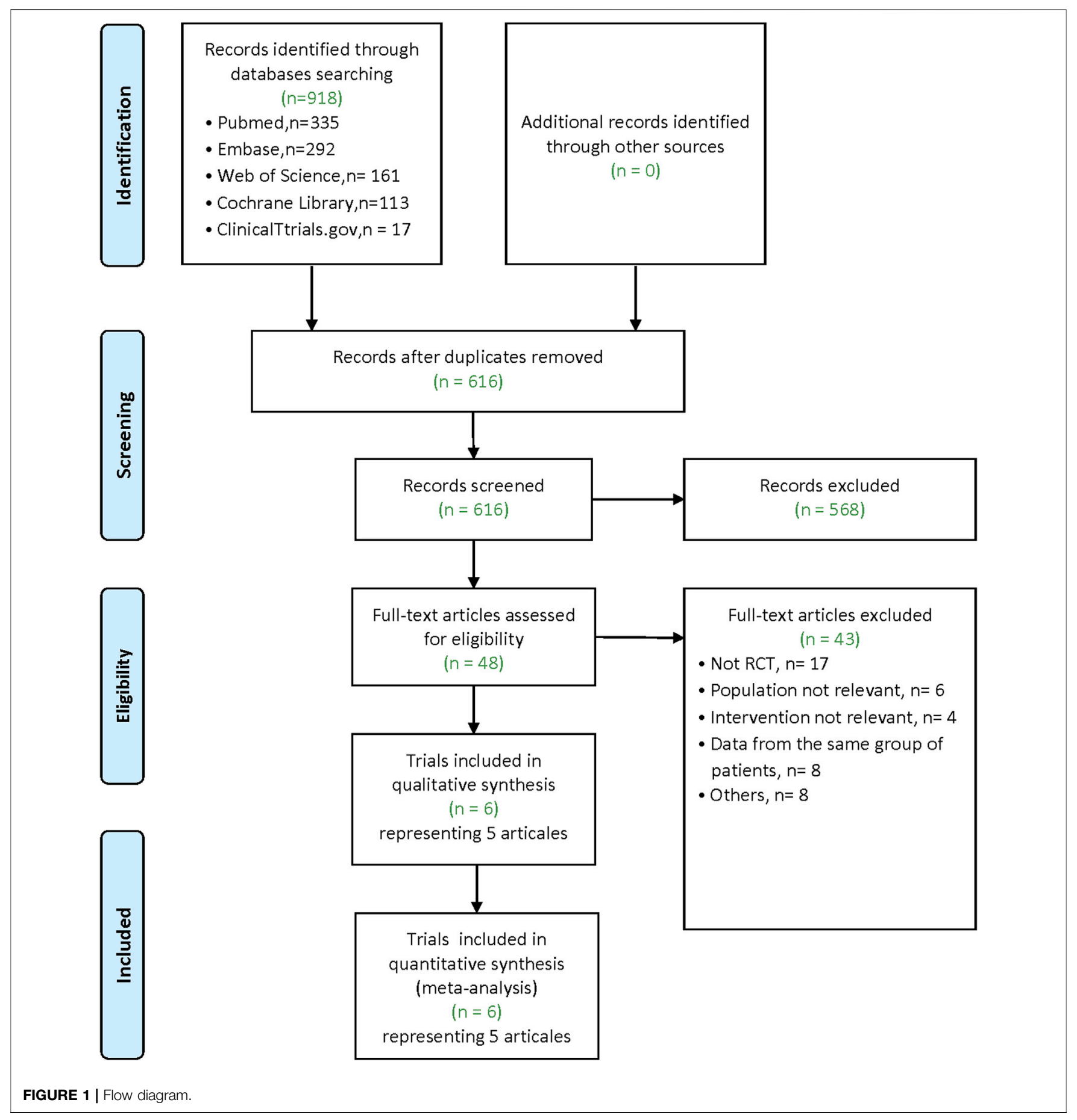

patients who received $\mathrm{ADA}(\mathrm{MD}=-0.05,95 \% \mathrm{CI},-0.07$ to $-0.02, p=0.0004)$. The $\mathrm{Q}$ statistic $(2.91$ on $5 \mathrm{df}, p=0.71)$ and $\mathrm{I}^{2}(0 \%)$ indicated low heterogeneity in the pooled studies. (Figure 4)

\section{Change in AC Cell Grade}

Of the six studies evaluating change in AC cell grade, five studies found that the ADA group's AC cell grade improved significantly more than the placebo group, while one trial reported the opposite result. The mean difference was ranging from -0.79 to $0.22(p<0.05)$. The pooled mean difference was -0.29 (95\% CI, -0.62 to 0.05$)$, not showing a significant difference between $\mathrm{ADA}$ and placebo groups. Both the Q statistic (38.58 on $5 \mathrm{df}, p<0.01$ ) and by $I^{2}(87 \%)$ demonstrated significant heterogeneity, which indicated that a random-effects model was preferable.

Additionally, we excluded each study's estimates to examine each study's influence on the overall results. After excluding 


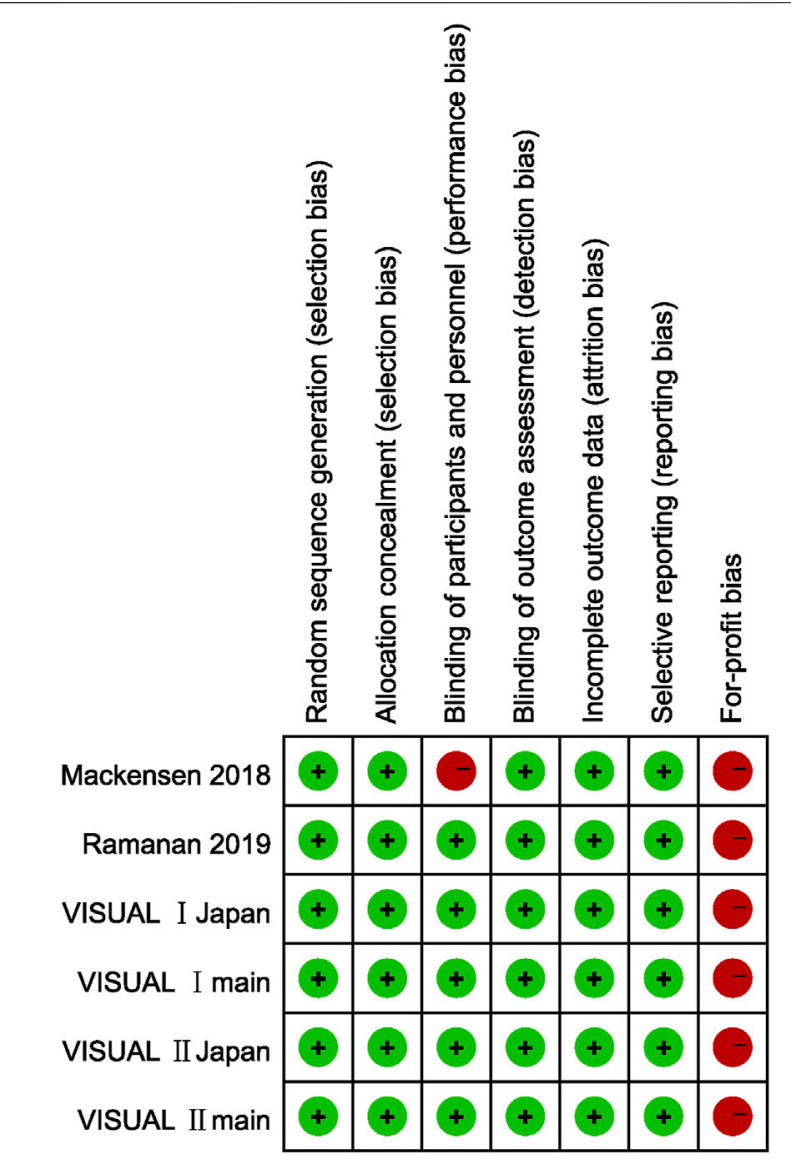

FIGURE 2 | Risk of bias summary.

VISUAL I Japan, the overall results have changed a lot that the diamond marker does not intersect with 0 , showing that the $\mathrm{AC}$ cell grade was significantly better in the ADA group than the placebo group ( $\mathrm{MD}=-0.39,95 \% \mathrm{CI}:-0.72,-0.06$ ).

In VISUAL I Japan, AC cell grade was numerically higher in the ADA group ( $\mathrm{MD}=0.22 ; 95 \% \mathrm{CI},-0.17,-0.61$ ) since one patient in the placebo group did not experience treatment failure from the beginning to end. Given the small sample size, this patient strongly impacted all the outcomes including $\mathrm{AC}$ cell grade. (Figure 5)

\section{Change in VH Grade}

Five studies reported Change in $\mathrm{VH}$ grade, and the mean difference was ranging from -0.54 to $-0.13(p<0.05)$. The pooled mean difference in $\mathrm{VH}$ grade change was -0.21 , with a $95 \%$ CI $(-0.32,-0.11)$, suggesting that the $\mathrm{VH}$ grade improved significantly more in the ADA group than the control group. Heterogeneity was low by the Q statistic (3.70 on $4 \mathrm{df}, p=0.45$ ) and by $\mathrm{I}^{2}(0 \%)$. After removing any one study, the pooled results did not change significantly, and the estimates in each case were well within the confidence range of the overall estimate. (Figure 6)

\section{Safety}

All six RCTs have safety information with 601 patients. A total of 3,494 AEs occurred during 406.5 patient-years, and the overall incidence of AEs was 8.60 events per patient-year. There were 2,237 AEs in the ADA group, and the overall incidence was 9.40 events per patient-year, numerically higher than those of the 1,257 total events and 7.79 events per patient-year in the placebo group. Table 3 shows the results of the safety. Six studies reported a total of 59 serious adverse events, of which $66 \%$ (39) occurred in the ADA group, indicating that the risk of serious adverse events in the ADA group was twice that of the placebo group.

The most common AEs were injection-site reactions and allergic reactions. The AEs reported in six studies were similar to those reported in previous studies and no new AEs occurred.

\section{Risk of Bias Across Studies}

It cannot be performed due to the small sample size.

\section{Discussion}

\section{Summary of Main Findings}

This meta-analysis of six RCTs including 605 patients systematically reviewed ADA's efficacy and safety in NIU. The results show that ADA almost halved the risk of NIU patients' treatment failure by significantly improving BCVA and reducing the $\mathrm{AC}$ cell grade and $\mathrm{VH}$ grade. The incidence of ADA-related AEs was generally low, and the safety profile was

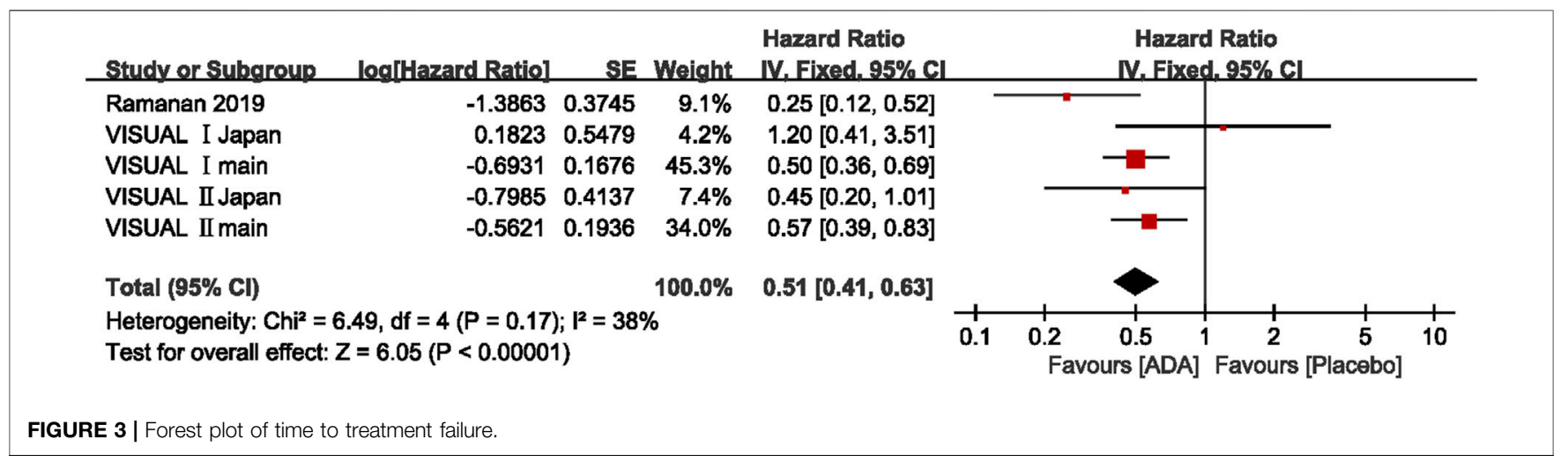




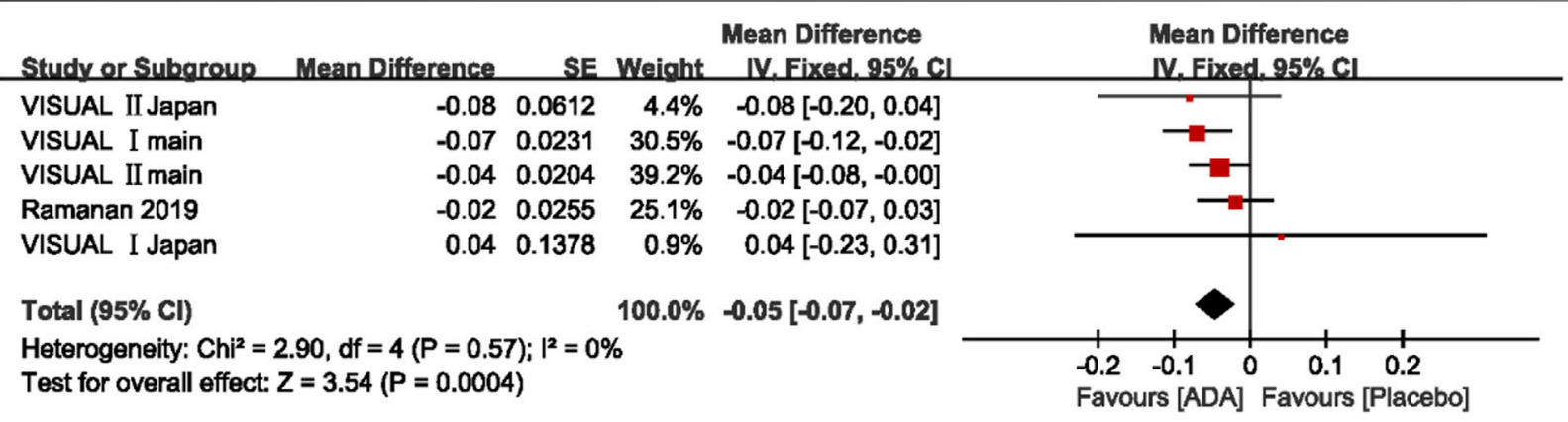

FIGURE 4 | Forest plot of BCVA.

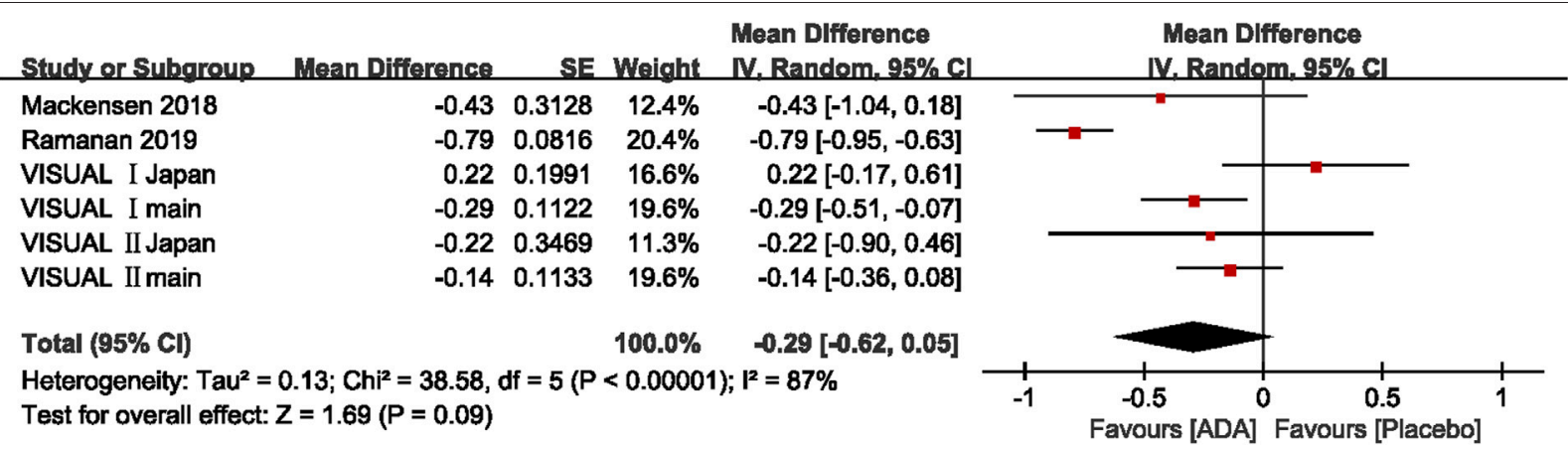

FIGURE 5 | Forest plot of AC cell grade.

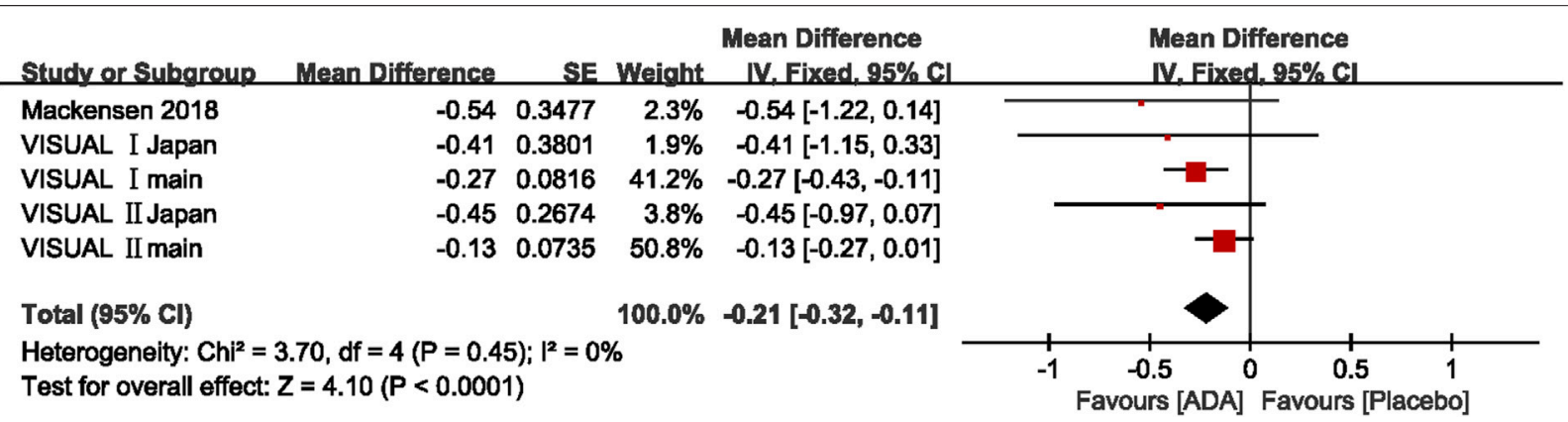

FIGURE 6 | Forest plot of VH grade.

similar to other reports in previous studies. Significant differences favoring ADA over placebo was seen for two secondary endpoints (change in BCVA and $\mathrm{VH}$ grade). Outcomes regarding $\mathrm{AC}$ cell grade in the $\mathrm{ADA}$ group were numerically superior to that in the placebo group.

\section{GRADE}

According to the GRADE, the certainty of the evidence concerning four efficacy outcomes were all judged as moderate. Table 4 shows the summary of GRADE's. Moderate-quality evidence shows that ADA considerably lowered the risk of treatment failure or visual impairment, moderately reduced $\mathrm{AC}$ cell grades and $\mathrm{VH}$ grades in NIU.

\section{Comparison to Prior Reviews}

The efficacy and safety results mentioned above were consistent with those of a meta-analysis by Shuai Ming et al. Their review included 20 non-RCTs and three RCTs. In contrast, our study included six RCTs and excluded non-RCTs, leading to a higher quality of evidence.

A similar article entitled "Anti-TNF Drugs for Chronic Uveitis in Adults-A Systematic Review and Meta-Analysis of Randomized Controlled Trials" has been published by Leal 
TABLE 1 | Characteristics of the included RCTs.

\begin{tabular}{|c|c|c|c|c|c|}
\hline & $\begin{array}{c}\text { Study, study } \\
\text { dates, setting, } \\
\text { type of } \\
\text { study, registration } \\
\text { number }\end{array}$ & $\begin{array}{l}\text { Sample size } \\
\text { (ADA/placebo), } \\
\text { mean age, } \% \\
\text { of females, } \\
\text { type of } \\
\text { uveitis, uveitis } \\
\text { duration }\end{array}$ & $\begin{array}{l}\text { Population: } \\
\text { diagnosis }\end{array}$ & $\begin{array}{l}\text { Intervention and } \\
\text { comparator }\end{array}$ & Outcomes \\
\hline $\begin{array}{l}\text { VISUAL I } \\
\text { main }\end{array}$ & $\begin{array}{l}\text { - August 2010-August } \\
2014 \\
\text { - } 67 \text { sites, } 18 \text { countries } \\
\text { - Multicenter, double- } \\
\text { masked, randomized } \\
\text { Placebo-controlled } \\
\text { Phase } 3 \text { trial } \\
\text { - NCT } 01138657\end{array}$ & $\begin{array}{l}\text { - } n=217(110 / 107) \text {, } \\
\text { age } 42.65(14.89) \\
\text { years } 57 \% \text { female } \\
\text { - Active uveitis } \\
\text { - Intermediate } 22 \% \text {, } \\
\text { posterior } 33 \% \text {, pan } \\
45 \% \\
\text { - Bilateral 91\%, } \\
\text { unilateral } 9 \% \\
\text { - } 45.53(62.53) \\
\text { months }\end{array}$ & $\begin{array}{l}\text { - Idiopathic } 37 \% \\
\text { - Sarcoidosis } 8 \% \\
\text { - Behçet's disease } 7 \% \\
\text { - VKH } 12 \% \\
\text { - Birdshot } \\
\text { chorioretinopathy } \\
20 \% \\
\text { - Multifocal choroiditis } \\
\text { and panuveitis } 5 \% \\
\text { - Other } 10 \%\end{array}$ & $\begin{array}{l}\text { - Intervention: subcutaneous ADA, } \\
80 \text { mg loading dose followed by } \\
40 \text { mg dose eow } \\
\text { - comparator: placebo } \\
\text { - prednisone burst for all at week } 0 \text {, } \\
\text { tapering to } 0 \text { by week < } 15\end{array}$ & $\begin{array}{l}\text { - Primary outcome: TTF } \\
\text { (worsening of one or more of AC } \\
\text { grade, VH grade, BCVA, or new } \\
\text { inflammatory lesions) at/after } \\
\text { week 6, one or more eyes } \\
\text { - Secondary outcomes: BCVA, } \\
\text { change in VH or AC grade, \% } \\
\text { change in CRT, time to MO, } \\
\text { change in VFQ-25 score, AEs }\end{array}$ \\
\hline $\begin{array}{l}\text { VISUAL \| } \\
\text { main }\end{array}$ & $\begin{array}{l}\text { - August 2010-May } \\
2015 \\
\text { - } 72 \text { sites, } 22 \text { countries } \\
\text { - Multicenter, double- } \\
\text { masked, randomized } \\
\text { placebo-controlled, } \\
\text { phase } 3 \text { trial }\end{array}$ & $\begin{array}{l}\text { - } n=225(114 / 111) \text {, } \\
\text { age } \\
42.56 \text { (13.43) years } \\
57 \% \text { female } \\
\text { - Inactive uveitis } \\
\text { - Intermediate } 21 \% \text {, } \\
\text { posterior 33\%, pan } \\
46 \% \\
\text { - Bilateral } 96 \%, \\
\text { unilateral } 4 \% \\
\text { - } 61.17(65.97) \\
\text { months }\end{array}$ & $\begin{array}{l}\text { - Idiopathic 31\% I } \\
\text { - Sarcoidosis 14\% } \\
\text { - Behçet's disease 7\% } \\
\text { - } \text { VKH } 23 \% \\
\text { - birdshot } \\
\text { chorioretinopathy } \\
13 \% \\
\text { - multifocal choroiditis } \\
\text { and Panuveitis 3\% } \\
\text { - other } 9 \%\end{array}$ & $\begin{array}{l}\text { - Intervention: subcutaneous ADA, } \\
80 \text { mg loading dose followed by } \\
40 \text { mg dose eow } \\
\text { - Comparator: placebo } \\
\text { - Prednisone burst for all at week } 2 \text {, } \\
\text { tapering to } 0 \text { by week } 15\end{array}$ & $\begin{array}{l}\text { - Primary outcome: TTF } \\
\text { (worsening of one or more of AC } \\
\text { grade, VH grade, BCVA, or new } \\
\text { inflammatory lesions) at after } \\
\text { week 2, one or more eyes } \\
\text { - Secondary outcomes: BCVA, } \\
\text { change in VH or AC grade, \% } \\
\text { change in CRT, time to MO, } \\
\text { change in VFQ-25 score, AEs }\end{array}$ \\
\hline $\begin{array}{l}\text { VISUAL I } \\
\text { Japan }\end{array}$ & $\begin{array}{l}\text { - August 2010-August } \\
2014 \\
\text { - } 7 \text { sites in Japan } \\
\text { - Multicenter, double- } \\
\text { masked, randomized } \\
\text { Placebo-controlled } \\
\text { Phase } 3 \text { trial } \\
\text { - NCT } 01138657\end{array}$ & $\begin{array}{l}\text { - } n=16(8 / 8), \text { age } \\
50.9(14.72) \text { years, } \\
59 \% \text { female } \\
\text { - Active uveitis } \\
\text { - Intermediate 6\%, } \\
\text { posterior } 13 \% \text {, pan } \\
81 \% \\
\text { - Bilateral } 87.5 \% \\
\text { Unilateral } 12.5 \% \\
\text { - } 57.15(75.70) \\
\text { months }\end{array}$ & $\begin{array}{l}\text { - Idiopathic } 44 \% \\
\text { - Sarcoidosis } 38 \% \\
\text { - Behçet's disease } \\
\\
12 \% \\
\text { - VKH } 6 \%\end{array}$ & $\begin{array}{l}\text { - Intervention: subcutaneous ADA, } \\
80 \text { mg loading dose followed by } \\
40 \text { mg dose eow } \\
\text { - Comparator: Placebo } \\
\text { - Prednisone burst for all at week 0, } \\
\text { tapering to } 0 \text { by week } 15\end{array}$ & $\begin{array}{l}\text { - Primary outcome: TTF } \\
\text { (worsening of one or more of AC } \\
\text { grade, VH grade BCVA, or new } \\
\text { inflammatory lesions) at/after } \\
\text { week 6, one or more eyes } \\
\text { - Secondary outcomes: BCVA, } \\
\text { change in VH or AC grade, \% } \\
\text { changein CRT, time to MO, } \\
\text { change in VFQ-25 score, AEs }\end{array}$ \\
\hline $\begin{array}{l}\text { VISUAL ॥ } \\
\text { Japan }\end{array}$ & $\begin{array}{l}\text { - August 2010-May } \\
2015 \\
\text { - } 7 \text { sites in Japan } \\
\text { - Multicenter, double- } \\
\text { masked, randomized } \\
\text { Placebo-controlled } \\
\text { Phase } 3 \text { trial } \\
\text { - NCT } 01124838\end{array}$ & $\begin{array}{l}\text { - } n=32(16 / 16), \text { age } \\
46.8(12.49) \text { years, } \\
59 \% \text { female } \\
\text { - Active uveitis } \\
\text { - Intermediate 0\%, } \\
\text { posterior 9\%, pan } \\
\text { 91\% } \\
\text { - Bilateral 91\%, } \\
\text { unilateral 9\% } \\
\text { - } 43.75(38.13) \\
\text { months }\end{array}$ & $\begin{array}{l}\text { - Idiopathic 25\% } \\
\text { - Sarcoidosis 31\% } \\
\text { - Behçet's disease 3\% } \\
\text { - VKH 38\% } \\
\text { - Other 3\% }\end{array}$ & $\begin{array}{l}\text { - Intervention: subcutaneous ADA, } \\
80 \text { mg loading dose followed by } \\
40 \text { mg dose eow } \\
\text { - Comparator: placebo } \\
\text { - Prednisone burst for all at week } 2 \text {, } \\
\text { tapering to } 0 \text { by week } 15\end{array}$ & $\begin{array}{l}\text { - Primary outcome: TTF } \\
\text { (worsening of one or more of AC } \\
\text { grade, VH grade, BCVA, or new } \\
\text { inflammatory lesions) at after } \\
\text { week 2, one or more eyes } \\
\text { - Secondary outcomes: BCVA, } \\
\text { change in VH or AC grade, \% } \\
\text { change in CRT, time to MO, } \\
\text { change in VFQ-25 score, AEs }\end{array}$ \\
\hline $\begin{array}{l}\text { Mackensen } \\
2018\end{array}$ & $\begin{array}{l}\text { - } \text { May 2007-August } \\
2012 \\
\text { - } 2 \text { centers } \\
\text { - Randomized, } \\
\text { prospective, controlled } \\
\text { Two-center clinical trial } \\
\text { - NCT } 00348153\end{array}$ & $\begin{array}{l}\text { - } n=25 \text { (10/15), age } \\
36 \text { years, } 60 \% \\
\text { female } \\
\text { - } \text { Active uveitis } \\
\text { - Anterior } 60 \% \text {, } \\
\text { posterior + pan } \\
40 \% \text { - } \\
\text { - } 94.56 \text { months }\end{array}$ & $\begin{array}{l}\text { - JIA: } 8 \% \\
\text { - Spondyloarthritis: } \\
16 \% \\
\text { - GPA/Behçet's/ } \\
\text { sarcoidosis: } 20 \% \\
\text { - HLA-B27B: } 24 \%\end{array}$ & $\begin{array}{l}\text { - Intervention: ADA (40 mg } \\
\text { subcutaneous injection eow) } \\
\text { - Comparator: blank } \\
\text { - Both arms continued previous } \\
\text { immunosuppressive therapy and } \\
\text { received a corticosteroid bolus of } \\
1 \text { mg/kg bw, with a fixed } \\
\text { standardized tapering scheme }\end{array}$ & $\begin{array}{l}\text { - Primary outcome: change in } \\
\text { visual acuity } \\
\text { - Secondary outcomes: extent of } \\
\text { macular edema, intraocular } \\
\text { inflammatory } \\
\text { Activity (SUN), the number of } \\
\text { treatment arm switchers, the } \\
\text { cumulative systemic } \\
\text { corticosteroid dose, AEs } \\
\text { (Continued on following page) }\end{array}$ \\
\hline
\end{tabular}


TABLE 1 | (Continued) Characteristics of the included RCTs.

\begin{tabular}{|c|c|c|c|c|c|}
\hline & $\begin{array}{c}\text { Study, study } \\
\text { dates, setting, } \\
\text { type of } \\
\text { study, registration } \\
\text { number }\end{array}$ & $\begin{array}{c}\text { Sample size } \\
\text { (ADA/placebo), } \\
\text { mean age, \% } \\
\text { of females, } \\
\text { type of } \\
\text { uveitis, uveitis } \\
\text { duration }\end{array}$ & $\begin{array}{l}\text { Population: } \\
\text { diagnosis }\end{array}$ & $\begin{array}{l}\text { Intervention and } \\
\text { comparator }\end{array}$ & Outcomes \\
\hline $\begin{array}{l}\text { Ramanan } \\
2019\end{array}$ & $\begin{array}{l}\text { - October 2011-June } \\
2015 \\
\text { - } 14 \text { centers in the } \\
\text { United Kingdom } \\
\text { - Randomized, parallel- } \\
\text { group, double-blind } \\
\text { Placebo-controlled } \\
\text { Multicenter clinical trial } \\
\text { - ISRCTN } 10065623\end{array}$ & $\begin{array}{l}\text { - } n=90(60 / 30), \text { age } \\
8.90(3.88) \text { years, } \\
78 \% \text { female } \\
\text { - } \text { Active uveitis } \\
\text { - Bilateral } 28 \%, \\
\text { unilateral } 72 \% \\
\text { - } 63.96(42.36) \\
\text { months }\end{array}$ & $\begin{array}{l}\text { JIA-associated } \\
\text { uveitis 100\% }\end{array}$ & $\begin{array}{l}\text { - Intervention: ADA ( } 20 \mathrm{mg} / 0.8 \mathrm{ml} \text { for } \\
\text { patients weighing <30 kg or } 40 \\
\text { mg/0.8 ml for patients weighing } \\
\geq 30 \mathrm{~kg} \text { by subcutaneous injection } \\
\text { eow) } \\
\text { - Comparator: placebo } \\
\text { - All participants received a stable } \\
\text { dose of MTX }\end{array}$ & $\begin{array}{l}\text { - Primary outcome: TTF } \\
\text { (multicomponent score as } \\
\text { defined by set criteria based on } \\
\text { the SUN criteria) } \\
\text { - Secondary outcomes: number } \\
\text { of participants failing treatment, } \\
\text { BCVA use of corticosteroids, } \\
\text { safety, tolerability, compliance }\end{array}$ \\
\hline
\end{tabular}

$A D A$, adalimumab; eow, every other week; AC, anterior chamber; $A E$, adverse event; CRT, central retinal thickness; JIA, juvenile idiopathic arthritis; LFP laser flare photometry; MTX, methotrexate; SL; SUN, standardization of uveitis nomenclature; TTF, time to treatment failure; VH, vitreous haze.

TABLE 2 | Summary of the results of individual studies.

\begin{tabular}{lcccc}
\hline & Time to treatment failure, HR & BCVA (change) (logMAR), MD & AC cell grade (change), MD & VH grade (change), MD \\
\hline VISUAL I main & $0.50(0.36,0.70)$ & $-0.07(-0.11,-0.02)$ & $-0.29(-0.51,-0.07)$ & $-0.27(-0.43,-0.11)$ \\
VISUAL II main & $0.57(0.39,0.84)$ & $-0.04(-0.08,0.01)$ & $-0.14(-0.37,0.08)$ & $-0.13(-0.28,0.01)$ \\
VISUAL I Japan & $1.20(0.41,3.54)$ & $0.04(-0.22,0.31)$ & $0.22(-0.17,0.61)$ & $-0.41(-1.15,0.34)$ \\
VISUAL II Japan & $0.45(0.20,1.03)$ & $-0.08(-0.20,0.04)$ & $-0.22(-0.90,0.46)$ & $-0.45(-0.98,0.07)$ \\
Mackensen 2018 & NA & NA & $-0.43(-1.05,0.18)$ & $-0.54(-1.22,0.14)$ \\
Ramanan 2019 & $0.25(0.12,0.51)$ & $-0.02(-0.07,0.02)$ & $-0.79(-0.96,-0.63)$ & NA \\
\hline
\end{tabular}

NA, not available; $M D$, mean difference; SD, standard deviation; $H R$, hazard ratio; BCVA, best-corrected visual acuity; $A C$, anterior chamber; VH, vitreous haze; logMAR, logarithm of the minimum angle of resolution.

TABLE 3 | summary of safety result.

\begin{tabular}{|c|c|c|c|c|c|c|c|c|c|}
\hline AE summery & $\begin{array}{c}\text { Sample size } \\
\text { (ADA/placebo) }\end{array}$ & \multicolumn{4}{|c|}{ ADA } & \multicolumn{4}{|c|}{ Placebo } \\
\hline VISUAL 1 main & $217(110 / 107)$ & 657 & 10.524 & 18 & 0.288 & 430 & 9.717 & 6 & 0.136 \\
\hline VISUAL 2 main & $225(114 / 111)$ & 831 & 8.790 & 13 & 0.138 & 642 & 9.050 & 10 & 0.141 \\
\hline $\begin{array}{l}\text { VISUAL } 1 \\
\text { Japan }\end{array}$ & $16(8 / 8)$ & 28 & 12.101 & 1 & 0.431 & 25 & 7.962 & 0 & 0 \\
\hline $\begin{array}{l}\text { Mackensen } \\
2018\end{array}$ & $25(10 / 15)$ & 54 & 7.665 & 1 & 0.142 & 30 & 5.475 & 0 & 0 \\
\hline $\begin{array}{l}\text { Ramanan } \\
2019\end{array}$ & $90(60 / 30)$ & 619 & 10.600 & 5 & 0.086 & 114 & 7.210 & 3 & 0.190 \\
\hline
\end{tabular}

$A D A$, adalimumab; $A E$, adverse event; $S A E$, serious adverse event.

et al. on May 24, 2019. Leal's study included three RCTs concerning two drugs: adalimumab and etanercept, with a sample size of 458. In comparison, our meta-analysis included six studies related to one single drug (ADA) with a sample size of 605. Moreover, the efficacy analysis was not conducted in Leal's study because of the significant heterogeneity between interventions. Our study pooled the six studies for efficacy analysis using uniform outcome measures such as BCVA, change in AC cell grade, and VH grade (SUN). This review is the first meta-analysis including only RCTs to summarize the current evidence regarding ADA's efficacy and safety in NIU, with strengths in the relatively higher quality of evidence and multicomponent primary endpoint. 
TABLE 4 | GRADE's summary of finding.

Adalimumab compared to Placebo for non-infectious uveitis

Patient or population: non-infectious uveitis

Setting:

Intervention: Adalimumab

Comparison: Placebo

\begin{tabular}{|c|c|c|c|c|}
\hline $\begin{array}{l}\text { Outcomes No of participants } \\
\text { (studies) }\end{array}$ & Relative effect $(95 \% \mathrm{CI})$ & $\begin{array}{c}\text { Anticipated absolute effects }(95 \% \mathrm{Cl}) \\
\text { Difference }\end{array}$ & Certainty & $\begin{array}{c}\text { What } \\
\text { happens }\end{array}$ \\
\hline Time to treatment failure & HR 0.51 (0.41 to 0.63) [Time to treatment & & $\bigoplus \oplus \oplus \bigcirc$ & - \\
\hline No of participants: 667 (5 RCTs) & failure] & & MODERATE & \\
\hline Change in BCVA (logMAR) & - & MD 0.05 lower (0.07 lower to 0.02 & $\oplus \oplus \oplus \bigcirc$ & - \\
\hline № of participants: 580 (5 RCTs) & & lower) & MODERATE & \\
\hline Change in $\mathrm{AC}$ cell grade & - & MD 0.29 lower (0.62 lower to 0.05 & $\bigoplus \bigoplus \oplus \bigcirc$ & - \\
\hline № of participants: 592 (6 RCTs) & & higher) & MODERATE & \\
\hline Change in $\mathrm{VH}$ grade & - & MD 0.21 lower (0.32 lower to 0.11 & $\oplus \oplus \oplus \bigcirc$ & - \\
\hline № of participants: 502 (5 RCTs) & & lower) & MODERATE & \\
\hline \multicolumn{5}{|c|}{$\begin{array}{l}\text { *The risk in the intervention group (and its } 95 \% \text { confidence interval) is based on the assumed risk in the comparison group and the relative effect of the intervention (and its } 95 \% \text { Cl). Cl: } \\
\text { Confidence interval; HR: Hazard Ratio; MD: Mean difference } \\
\text { GRADE Working Group grades of evidence } \\
\text { High certainty: We are very confident that the true effect lies close to that of the estimate of the effect } \\
\text { Moderate certainty: We are moderately confident in the effect estimate: The true effect is likely to be close to the estimate of the effect, but there is a possibility that it is substantially different } \\
\text { Low certainty: Our confidence in the effect estimate is limited: The true effect may be substantially different from the estimate of the effect } \\
\text { Very low certainty: We have very little confidence in the effect estimate: The true effect is likely to be substantially different from the estimate of effect }\end{array}$} \\
\hline
\end{tabular}

\section{Limitations}

The principal limitation is that high heterogeneity was observed in our analysis. Differences in types of uveitis, patient's age, concomitant medications, and outcome measures may contribute to the heterogeneity. It is important to note that we did not restrict participants' age, so we recruited both adult and pediatric patients in this meta-analysis. In adults, ADA's main indications in NIU are intermediate, posterior forms of uveitis and panuveitis. In children with uveitis, ADA's main indication is JIA-associated uveitis and idiopathic uveitis, which is mainly anterior uveitis. We originally planned to conduct subgroup analysis in this article based on the location and type of uveitis, but due to the small sample size and the inability to extract relevant data from some studies, we gave up the subgroup analysis. In the future, more studies on the treatment of single uveitic disease with ADA are needed.

Besides, it is well known that RCT is not an ideal type of study to identify safety results because the relatively small sample size and short follow-up time make it challenging to identify rare adverse events. Therefore, the RCTs included in this review are not sufficient to study AEs thoroughly.

A further limitation was that the four VISUAL trials were sponsored by one pharmaceutical company (AbbVie) and the remaining two studies had participants who received remuneration such as the speaker's fees from AbbVie, which may seriously affect the results.

\section{Implication}

In the future, independent non-company sponsored RCTs are needed to further provide more objective and robust evidence. Besides, it is necessary to further compare ADA with conventional immunosuppressors regarding efficacy and safety in NIU.

\section{CONCLUSION}

This meta-analysis of six RCTs comparing ADA with placebo for NIU further confirmed that ADA considerably lowered the risk of treatment failure or visual impairment, and moderately reduced $\mathrm{AC}$ cell grades and $\mathrm{VH}$ grades with slightly more AEs.

\section{DATA AVAILABILITY STATEMENT}

The original contributions presented in the study are included in the article/Supplementary Material; further inquiries can be directed to the corresponding author/s.

\section{FUNDING}

Supported by Sichuan Provincial Department of Science and Technology, China (2019YFH0117).

\section{AUTHOR CONTRIBUTIONS}

Conceptualization: BL. Data curation: BL and HL. Methodology: BL and ZL. Drafting of the article: BL and HL. Final approval: BL and YZ. 


\section{REFERENCES}

Airody, A., Heath, G., Lightman, S., and Gale, R. (2016). Non-infectious uveitis: optimising the therapeutic response. Drugs 76 (1), 27-39. doi:10.1007/s40265015-0502-y

Balevic, S. J., and Rabinovich, C. E. (2016). Profile of adalimumab and its potential in the treatment of uveitis. Drug Des. Devel Ther. 10, 2997-3003. doi:10.2147/ dddt.S94188

Burmester, G. R., Panaccione, R., Gordon, K. B., McIlraith, M. J., and Lacerda, A. P. M. (2013). Adalimumab: long-term safety in 23458 patients from global clinical trials in rheumatoid arthritis, juvenile idiopathic arthritis, ankylosing spondylitis, psoriatic arthritis, psoriasis and crohn's disease. Ann. Rheum. Dis. 72 (4), 517-524. doi:10.1136/annrheumdis-2011-201244

Cordero-Coma, M., and Sobrin, L. (2015). Anti-tumor necrosis factor- $\alpha$ therapy in uveitis. Surv. Ophthalmol. 60 (6), 575-589. doi:10.1016/j.survophthal.2015. 06.004

Dick, A. D., Tundia, N., Sorg, R., Zhao, C., Chao, J., Joshi, A., et al. (2016). Risk of Ocular Complications in patients with noninfectious intermediate uveitis, posterior uveitis, or panuveitis. Ophthalmology 123 (3), 655-662. doi:10. 1016/j.ophtha.2015.10.028

Durrani, O. M., Tehrani, N. N., Marr, J. E., Moradi, P., Stavrou, P., and Murray, P. I. (2004). Degree, duration, and causes of visual loss in uveitis. Br. J. Ophthalmol. 88 (9), 1159-1162. doi:10.1136/bjo.2003.037226

Jabs, D. A., Nussenblatt, R. B., and Rosenbaum, J. T. (2005). Standardization of uveitis nomenclature for reporting clinical data. results of the first international workshop. Am. J. Ophthalmol. 140 (3), 509-516. doi:10.1016/j.ajo.2005.03.057

Jabs, D. A., Busingye, J., and Busingye, Jacqueline. (2013). Approach to the diagnosis of the uveitides. Am. J. Ophthalmol. 156 (2), 228-236. doi:10. 1016/j.ajo.2013.03.027

Jaffe, G. J., Dick, A. D., Brézin, A. P., Nguyen, Q. D., Thorne, J. E., Kestelyn, P., et al. (2016). Adalimumab in patients with active noninfectious uveitis. N. Engl. J. Med. 375 (10), 932-943. doi:10.1056/NEJMoa1509852

Levy-Clarke, G., Jabs, D. A., Read, R. W., Rosenbaum, J. T., Vitale, A., and Van GelderVan Gelder, R. N. (2014). Expert panel recommendations for the use of anti-tumor necrosis factor biologic agents in patients with ocular inflammatory disorders. Ophthalmology 121 (3), 785-796. doi:10.1016/j. ophtha.2013.09.048

Llorenç, V., Mesquida, M., Sainz de la Maza, M., Keller, J., Molins, B., Espinosa, G., et al. (2015). Epidemiology of uveitis in a western urban multiethnic population. the challenge of globalization. Acta Ophthalmol. 93 (6), 561-567. doi:10.1111/ aos. 12675

Miloslavsky, E. M., NadenBijlsma, R. P., Bijlsma, J. W. J., Brogan, P. A., Brown, E. S., Brunetta, P., et al. (2017). Development of a glucocorticoid toxicity index (gti) using multicriteria decision analysis. Ann. Rheum. Dis. 76 (3), 543-546. doi:10.1136/annrheumdis-2016-210002
Ming, S., Xie, K. H. He., He, H., Li, Y., and Lei, B. (2018). Efficacy and safety of adalimumab in the treatment of non-infectious uveitis: a meta-analysis and systematic review. Drug Des. Devel. Ther. 12, 2005-2016. doi:10.2147/dddt. S160431

Nguyen, Q. D., Merrill, P. T., Jaffe, G. J., Dick, A. D., Kurup, S. K., Sheppard, J., et al. (2016). Adalimumab for prevention of uveitic flare in patients with inactive non-infectious uveitis controlled by corticosteroids (VISUAL II): a multicentre, double-masked, randomised, placebo-controlled phase 3 trial. The Lancet 388 (10050), 1183-1192. doi:10.1016/s0140-6736(16)31339-3

Niederer, R. L., Sharief, L., Bar, A., Lightman, S. L., and Tomkins-Netzer, O. (2017). Predictors of long-term visual outcome in intermediate uveitis. Ophthalmology 124 (3), 393-398. doi:10.1016/j.ophtha.2016.11.013

Nussenblatt, R. (2005). Treating intraocular inflammatory disease in the 21st century. Arch. Ophthalmol. 123 (7), 1000-1001. doi:10.1001/archopht.123.7. 1000

Schwartzman, S., and Schwartzman, M. (2015). The use of biologic therapies in uveitis. Clinic Rev. Allerg. Immunol. 49 (3), 307-316. doi:10.1007/s12016-0148455-6

Sen, H. N., Vitale, S., Gangaputra, S. S., Nussenblatt, R. B., Liesegang, T. L., LevyClarke, G. A., et al. (2014). Periocular corticosteroid injections in uveitis. Ophthalmology 121 (11), 2275-2286. doi:10.1016/j.ophtha.2014.05.021

Shamseer, L., Moher, D. D. G., Clarke, M., Ghersi, D., Liberati, A., Petticrew, M., et al. (2015). Preferred reporting items for systematic review and meta-analysis protocols (prisma-p) 2015: elaboration and explanation. BMJ 349, g7647. doi:10.1136/bmj.g7647

Suhler, E. B., Lowder, C. Y., Goldstein, D. A., Giles, T., Lauer, A. K., Kurz, P. A., et al. (2013). Adalimumab therapy for refractory uveitis: results of a multicentre, open-label, prospective trial. Br. J. Ophthalmol. 97 (4), 481-486. doi:10.1136/ bjophthalmol-2012-302292

Suhler, E. B., Thorne, J. E., Mittal, M., Betts, K. A., Tari, S., Camez, A., et al. (2017). Corticosteroid-related adverse events systematically increase with corticosteroid dose in noninfectious intermediate, posterior, or panuveitis. Ophthalmology 124 (12), 1799-1807. doi:10.1016/j.ophtha.2017.06.017

Wakefield, D., and Chang, J. H. (2005). Epidemiology of uveitis. Int. Ophthalmol. Clin. 45 (2), 1-13. doi:10.1097/01.iio.0000155938.83083.94

Conflict of Interest: The authors declare that the research was conducted in the absence of any commercial or financial relationships that could be construed as a potential conflict of interest.

Copyright (c) $2021 \mathrm{Li}, \mathrm{Li}$, Zhang and Zheng. This is an open-access article distributed under the terms of the Creative Commons Attribution License (CC BY). The use, distribution or reproduction in other forums is permitted, provided the original author(s) and the copyright owner(s) are credited and that the original publication in this journal is cited, in accordance with accepted academic practice. No use, distribution or reproduction is permitted which does not comply with these terms. 